\title{
Distinguishing DD from SLI. Language profiles of Italian dyslexic children with and without specific language impairment
}

\author{
Emanuele Casani \\ Università Ca' Foscari Venezia \\ Dipartimento di Studi Linguistici e Culturali Comparati \\ Ca' Bembo. Dorsoduro 1075, Fondamenta Tofetti \\ 30123 Venezia (Italia) \\ E-mail: emanuele.casani@unive.it
}

\section{DISTINGUISHING DD FROM SLI. LANGUAGE PROFILES OF ITALIAN DYSLEXIC CHILDREN WITH AND WITHOUT SPECIFIC LANGUAGE IMPAIRMENT}

ABSTRACT: Although Developmental Dyslexia (DD) and Specific Language Impairment (SLI) are two distinct disorders, DD and SLI children can show comparable difficulties with written and oral skills which may make a def inite diagnosis difficult. This study explores reading and its relations with some sensitive skills (rapid nam ing, syntactic comprehension, and syntactic production) in a sample of Italian DD children with and withou SLI to investigate possible distinctive patterns for different disorder profiles. DD children with and withou SLI show comparable reading performances but differ in that SLI children have additional naming and clitic production deficits. Typical error patterns emerge for rapid naming by SL children and typical compensation strategies for clitic production by SLI and younger DD children. Quantity and quality of correlations between reading and other skills are proportional to the severity of the impairment. The use of an ad hoc reading test, as well as a possible implementation of the syntactic comprehension test, is suggested.

KEYWORDS: developmental dyslexia (DD); specific language impairment (SLI); reading; rapid naming; syntactic comprehension; syntactic production; clitic pronouns.

SUMMARY: 1 . Introduction. 2. The study. 3. Results. 4. Discussion. 5 . Conclusion
DISTINGUIR LA DD DEL SLI. PERFILES LINGÜÍSTICOS DE NIÑOS DISLÉXICOS ITALIANOS CON Y SIN TRASTORNO ESPECÍFICO DEL LENGUAJE

RESUMEN: Aunque la Dislexia del Desarrollo (DD) y el Trastorno Específico del Lenguaje (TEL) son dos trastornos distintos, los niños con DD y los niños con TEL pueden mostrar dificultades similares en las habilidades orales y escritas, lo que puede dificultar un diagnóstico definido. Este estudio explora la lectura y sus relaciones con algunas habilidades susceptibles (denominación rápida, comprensión sintáctica y producción sintáctica) en una muestra de niños italianos disléxicos con presencia y ausencia del TEL, con el fin de investigar posibles patrones distintivos para los diferentes perfiles de trastorno. Los niños disléxicos con y sin TEL muestran rendimientos de lectura similares, pero difieren en que los niños con TEL tienen deficiencias adicionales de denominación rápida y de producción de pronombres clíticos. Algunos patrones de error típicos emergen en la denominación rápida cuando se trata de niños con TEL y algunas estrategias de compensación típicas emergen en la producción de pronombres clíticos por parte de los niños con TEL y también en niños disléxicos más pequeños. La cantidad y la calidad de las correlaciones entre la lectura y otras habilidades son proporcionales a la severidad de los trastornos. Se sugiere finalmente el uso de una prueba de lectura ad hoc, así como una posible implementación de la prueba de comprensión sintáctica.

PALABRAS ClAves: dislexia de desarrollo (DD); trastorno específico del lenguaje (TEL); lectura; nombramiento rápido; comprensión sintáctica; producción sintáctica; pronombres cliticos.

SUMARIO: 1 . Introducción. 2 . El estudio. 3. Resultados. 4. Discusión. 5. Conclusiones.
DISTINGUER LA DD DU TSL. PROFILS LINGUISTIQUES D'ENFANTS ITALIENS DYSLEXIQUES AVEC OU SANS TROUBLES SPECIFIQUES DU LANGAGE

RÉSUMÉ: La Dyslexie Développementale (DD) et le Trouble Spécifique du Langage (TSL) sont deux troubles distincts, pourtant les enfants DD et TSL peuven présenter des difficultés comparables au niveau de leurs compétences écrites et orales, ce qui peut rendre difficile la pose de diagnostic. Cette étude explore la lecture et ses relations avec certaines compétences à risque (dénomination rapide, compréhension et production syntaxiques) chez un échantillon d'enfants DD italiens avec ou sans TSL, afin de rechercher d'éventuels schémas distinctifs pour les différents profils de troubles. Les enfants DD avec et sans TSL affichent des performances en lecture comparables, mais diffèrent en ce que les enfants TSL présentent des déficits au niveau de la dénomination rapide et de la production de pronoms clitiques. Des patterns d'erreur typiques apparaissent dans la dénomination rapide chez les enfants avec TSL et des stratégies de compensation typiques pour la production de pronoms clitiques chez les enfants avec TSL et les DD plus jeunes. La nature et le nombre de corrélations entre les performances de lecture et les autres compétences sont proportionnels à la gravité du déficit. L'utilisation d'un test de lecture ad hoc ainsi qu'une implémentation possible du test de compréhension syntaxique sont suggérées.

MOTS CLÉS: dyslexie développementale (DD); trouble spécifique du langage (TSL); lecture; dénomination rapide; compréhension syntaxique; production syntaxique; pronoms clitiques.

SOMMAIRE: 1 . Introduction. 2. L'étude. 3. Résultats. 4. Discussion. 5. Conclusion.
Fecha de Recepción Fecha de Revisión Fecha de Aceptación Fecha de Publicación
$05 / 02 / 2019$

$17 / 04 / 2019$

$10 / 05 / 2019$

$01 / 12 / 2020$ 


\section{Distinguishing DD from SLI. Language profiles of Italian dys- lexic children with and without specific language impairment}

\section{EMANUELE CASANI}

\section{INTRODUCTION}

There is a wide consensus on the different natures of Developmental Dyslexia (DD) and Specific Language Impairment (SLI) (Catts et al., 2005). Both of them occur in the presence of normal IQ and an adequate socio-developmental environment provided the absence of any neuromotor disorder that may interfere with written and oral language, respectively. Under these conditions, DD can manifest as slow and inaccurate word recognition (Peterson and Pennington, 2012), whereas SLI as a specific difficulty in acquiring oral language (Leonard, 1998). Both disorders are widely heterogeneous. Recent cross-linguistic research on acquired dyslexia identified at least 10 types, which can be valid for developmental forms, too (Friedmann and HaddadHanna, 2014), and led to the identification of 19 different types of DD (Friedmann and Coltheart, 2018). These can be roughly divided into three main groups: 'peripheral dyslexias', which depend on a deficit in the orthographicvisual analysis stage and result into difficulties in encoding letter identity as well as their position and bindings within words (Humphreys et al., 1990); 'central dyslexias', which depend on a deficit in the lexical or sublexical route (ibidem): in the former case, every word is read by grapheme-to-phoneme conversion, with considerable difficulty in reading irregular words, homophones, and potentiophones, whereas in the latter case the difficulty lies in reading new words and non-words; 'deep dyslexias', which involve both the lexical and the sublexical route Stuart and Howard, 1995), and result into considerable difficulty in reading abstract words, function words, and nonwords, with necessary resort to the semantic route.

Great heterogeneity is reported for SLI, too, as different components of the language can be selectively impaired, thus resulting into a modular disorder which can affect, either singularly or in combination, phonology (Bishop, 2006), syntax and morphosyntax (van der Lely, 2005), lexicon (Dockrell and Messer, 2007), semantics (McGregor et al., 2002), and pragmatics (Friedmann and Novogrodski, 2008).

DD and SLI present many overlaps, so that SLI is a strong risk factor for the development of a reading disorder, in particular in the presence of a phonological deficit (Nithart et al., 2009). Many SLI-children experience reading problems in school (Bishop et al., 2009), as well as many DD-children show undiagnosed language problems which are very similar to those displayed by SLI children (Guasti, 2013). These can involve reading comprehension (Hoover and Gough, 1990), (morpho)syntactic processing (Guasti et al., 2015), word and non-word repetition (Miles, 1993), and rapid naming of visual stimuli (Swan and Goswami, 1997). 


\subsection{READING COMPREHENSION}

In the so-called "direct dyslexia" or "reading without meaning" (Castles et al., 2010, Seymour and Evans, 1992), the impairment would not lie in the grapheme to phoneme conversion but in the comprehension of written words, with effects on the conceptual-semantic system. According to the 'Simple View of Reading' (Hoover and Gough, 1990), significant reading comprehension deficits are predictable among SLI and DD subjects, as a consequence of deficits in either listening comprehension, as in SLI, or decoding, as in DD. Spencer et al. (2014) argue that "individuals with problems in reading comprehension that are not attributable to poor word recognition have comprehension problems that are general to language comprehension rather than specific to reading". Bishop and Snowling (2004), disagreeing with the 'Simple View of Reading', argue that reading comprehension deficits differ between SLI and DD in that SLI subjects present reading and listening comprehension deficits in addition to phonological deficits. "This accounts for the finding that problems on reading comprehension are common in SLI (Bishop and Adams, 1990) but less so in classic dyslexia (Frith and Snowling, 1983)" (Bishop and Snowling, 2004, p. 876). In this vein, Talli et al. (2016) state that children with SLI show significant and more frequent deficits in reading comprehension compared to both controls (matched for age and reading level) and DD-children. Clarke et al. (2010) demonstrate that an oral-language weakness underlies specific reading-comprehension difficulties, which can be effectively improved by a suitable teaching intervention. In conclusion,

while it is clear that decoding inefficiency will lead to reading comprehension difficulties (e.g., Perfetti, 1985), not all children who have comprehension difficulties have impairments in basic decoding, nor do they experience a phonological bottleneck [...]. Poor comprehenders do, however, have weaknesses in other aspects of language skill with deficits at both lower (e.g., vocabulary knowledge) and higher levels (e.g., inference generation, understanding figurative language) being reported [...]" (Nation, 2005).

\subsection{RAPID NAMING}

Rapid naming involves a coordinated system of perception, memory, lexis, and articulation (Wolf, 2001). Slowness in the rapid naming of visual stimuli is a typical problem of both SLI (McGregor et al., 2002) and DD (Swan and Goswami, 1997). SLI-children are less accurate than typically developing (TD) children (Befi-Lopes et al., 2010). Proportionally, their error typologies are more semantic and phonological than structural, namely, they rarely mistake images for other visually similar objects, and the error frequency seems to be related to the nature of their impairment. Children with an expressive language deficit are more prone to make phonological errors, whereas children with a mixed language deficit tend to make semantic errors 
(Lahey and Edwards, 1999). Naming speed is strictly related to early indicators of phonological awareness, such as rhymes, sound repetition, and, in early school years, grapheme recognition, so that it has been considered as a strong predictor of the access to phonological codes that are stored in longterm memory (Decker et al., 2013). Denckla and Rudel (1976) showed that DD-children name fewer objects than non-dyslexic children and perform slower than controls, even those suffering from minimal brain dysfunction. However, unlike dysphasic subjects, dyslexic subjects rarely make structural errors. A longitudinal study on eight dyslexic cases (Wolf and Obregon, 1992) revealed that problems in lexicon retrieval persist across primary school and showed a correlation between lexicon retrieval deficits and the subsequent onset of a proportional reading disorder. Other studies (Manis et al., 1997) confirm rapid naming as a significant predictor of reading disorders (Wolf et al., 1986). This correlation sometimes persists across adolescence, when dyslexic teenagers can perform comparably with TD children (Fawcett and Nicolson, 1994), and even during adulthood (Wolff et al., 1990). Slowness in naming tasks is a predictor of difficulties in written-text decoding rather than in written-text comprehension (Wolf and Obregon, 1992), and it would be related more to reading speed than to reading accuracy (Ziegler et al., 2010). However, such a claim may be partial. According to Talli et al. (2015), this is because research on naming performances has mainly focused on speed (Vaessen et al., 2009), whereas accuracy has mainly been examined in relation to phonemic awareness, except for rare exceptions (Martin et al., 2010; Patel et al., 2004).

\section{3. (MORPHO)SYNTACTIC PROCESSING}

Cross-linguistic research demonstrates that children with SLI face particular problems in processing complex syntactic structures (Bishop, 1997), such as relative clauses, in particular object extracted center-embedded relative clauses (Friedmann and Novogrodski, 2007). Hebrew SLI-children have difficulties with Wh- questions, particularly with object Wh- questions, whose comprehension is worse than subject Wh- questions. These problems are ascribed to difficulties with syntactic movement of the NP (Friedmann and Novogrodsky; 2011), and to the 'Computational Grammatical Complexity Hypothesis', according to which a core deficit in the computational system of subjects with grammar SLI affects syntactic dependencies at the clause level (van der Lely et al., 2011). Cross-linguistic comprehension problems are also reported for passive clauses (Bishop et al., 2000); structuredependent relations (van der Lely and Stollwerk, 1997: 248); binding principles, with particular problems in applying principles $\mathrm{A}$ and $\mathrm{B}$ of the binding theory (Chomsky, 1981), probably due to a difficulty in computing the local domain and in finding the proper antecedent of the pronoun (van der Lely and Stollwerk, 1997); morphemes that cumulate more morphological information, such as the English 3rd person “-s", which marks agreement as well 
as tense (Clahsen et al., 1997), or Romance clitic pronouns. Production of third-person direct object clitic pronouns (DOcl) deserves a special reference, as significant percentages of omissions among SLI children are reported in all Romance languages and Greek. Omissions are particularly frequent in Italian and French (Manika, 2014), where they are a robust clinical marker of SLI (Bortolini et al., 2006). In Italian, high sensitivity and specificity of this clinical marker are reported until age 10 (Arosio et al., 2014).

Spanish SLI-children face difficulties employing pragmatic maxims, in particular the 'maxim of informativeness' (Grice, 1975), as well as understanding the logical meaning of quantifiers (Katsos et al., 2011), in particular when these require to draw scalar implicatures (Arosio et al., 2010). Their performance is comparable to that of younger typically developing children, whereas performances of both SLI and TD children reveal to be poorer with pragmatics than with logical quantification meaning (Katsos et al., 2011).

SLI children are less accurate in repeating negative and interrogative than declarative and imperative sentences (Menyuk and Looney, 1972), and produce less polar inverted sentences than TD children (Leonard, 1995).

Most of the above-mentioned syntactic difficulties are experienced by DDsubjects, too. Problems are reported for the comprehension of relative clauses, in particular object relative clauses (Wiseheart et al., 2009). In Italian, the performance of adults with dyslexia is comparable to that of teenagers in the comprehension and production of relatives; it is also below adults' performance in the production of passives (Cardinaletti and Volpato, 2015). Italian and Dutch DD-children show more difficulty than controls in interpreting universally quantified NPs in quantifier spreading contexts (Fiorin, 2010). Problems are reported for tough sentences (Byrne, 1981), namely sentences in which the syntactic subject of the main verb is logically the object of an embedded non-finite verb. Some Italian 9-year-old DD subjects show non-adult-like competence in handling imperfective contexts. The reason may lie in the fact that the interpretation of imperfective sentences triggers the computation of a scalar implicature, as it requires the construction of a reference set between complete past events and ongoing events (Parsons, 1990) unless the case of a reference to complete imperfective events (Fiorin, 2010). Nevertheless, Guasti (2013) does not agree on the fact that DD-children have problems in understanding quantifiers, even requiring the generation of scalar implicatures. The comprehension of negative sentences can also be problematic for DD-children due to processing limitations. They show, in fact, a significantly poorer performance than controls when asked to evaluate sentences containing the negative quantifier nessuno (nobody) (Vender and Delfitto, 2010). Finally, problems are reported for clitic pronouns, as Italian DD-children are generally less accurate than TD-children in comprehension tasks matching an utterance with/without a clitic pronoun to a cartoon. They show extreme individual variability, by performing at ceiling or opting for clitic omission. Phonological and morphosyn- 
tactic properties of object clitics seem to influence their performance. In particular, the direct object clitic pronoun $l i$ appears weaker than the indirect object clitic pronoun gli, and gender errors, besides omissions, are present (Zachou et al., 2013). Specific problems with DOcl by DD-children might be due to the possible presence of an undiagnosed SLI (Guasti, 2013), or to the particular sensitivity of clitic (morpho)syntactic properties in revealing language difficulties (Zachou et al., 2013).

\section{THE STUDY}

The above-mentioned literature shows that dyslexic children can experience most language difficulties that are typical of SLI. These can affect reading comprehension, rapid naming of visual stimuli, and the interpretation of complex (morpho)syntactic structures. The present study intends to explore these abilities in a sample of Italian DD children with and without SLI to investigate possible linguistic patterns that might be distinctive of different disorder profiles.

\subsection{SUBJECTS}

Fifty-three out of 61 (34 F and $27 \mathrm{M}$ ) Italian primary-school children who provided informed parental consent and expressed their assent to participate in the research met inclusion criteria (see section 1). Among them, 17 subjects (age 7;2 - 10;11 $(M=9 ; 7, S D=1 ; 1)$ had a diagnosis of DD; 4 subjects (age $6 ; 7-8 ; 11(M=7 ; 11, S D=1 ; 1))$ of mixed SLI plus reading problems ${ }^{1} ; 32$ subjects (age 7;11 - 11;3 $(M=9 ; 5, S D=1 ; 0))$ were TD-children. Diagnoses were made by the Italian public national health system (ASL) or by authorized private clinical centers.

Since the age difference between the experimental groups was significant $(H(2)=6.94, p=0.026, \mathrm{DDG}>\mathrm{SLIG}, p=0.026)$, the sample was divided into the following subgroups:

- a younger sample of 5 DD-children (age $7 ; 2-9 ; 0(M=8 ; 3, S D=0 ; 10)$ ), henceforth DDG1; the 4 age-matched SLI-children (age 6;7 - 8;11 $(M=$ $8 ; 0, S D=1 ; 0)$ ), henceforth SLIG; and 20 age-matched TD controls (age $7 ; 11-9 ; 3(M=8 ; 8, S D=0 ; 5))$, henceforth CG1;

- an elder group of 12 DD-children (age 9;5 - 10;11 $(M=10 ; 2, S D=0 ; 6)$ ), henceforth DDG2; and 12 age-matched TD controls (age 9;6-11;3 $(M=$ $10 ; 7, S D=0 ; 6)$ ), henceforth CG2.

\footnotetext{
${ }^{1} \mathrm{DD}$ or problems in reading prerequisites
} 


\subsection{MATERIAL, PROCEDURES, AND ANALYSES}

Reading was tested through the MT-2 for the primary school (Cornoldi and Colpo, 2011), a clinical battery that was employed until $2016^{2}$ to implement reading diagnoses. Decoding accuracy (error number) and decoding speed (syllables per second) are assessed through a printed text which is read aloud. Reading comprehension is assessed through a different calibrated printed text, which is read silently and followed by a set of 10/12 four-choice questions. The score is given by the number of correct answers.

Rapid naming and syntactic comprehension were tested through the BVN 5-11 (Neuropsychological Assessment Battery) (Bisiacchi et al., 2005). The rapid naming test consists of 20 black and white printed drawings preceded by a six-item practice trial to be named as fast as possible from left to right and from top to bottom as if reading. Naming accuracy (number of properly named figures) and naming speed (number of objects per second) were registered.

The syntactic comprehension test is a reduced adaptation of the 1983 version of the TROG (Bishop, 2009). It consists of 18 items, the first 8 are focused on lexicon and the other 10 are focused on grammar. For each item, the child must match the sentence uttered by the administrator with one image out of four. Global and partial (lexicon-focused and grammar-focused) syntactic comprehension scores are computed.

Syntactic production was assessed through a clitic production test (Arosio et al., 2014), which is presented on a PPT. Each item consists of a twoslide mini cartoon with a digitally recorded voice of an Italian male native speaker creating a restrictive context which, according to Italian pragmatic rules, should elicit a DOcl. The 12 experimental items are preceded by 5 practice trials. In this experiment, a sentence containing a felicitous DOcl received one point, whereas sentences containing a wrong clitic pronoun as well as grammatical non-target sentences scored zero.

A response analysis was conducted for each ability.

Tests were administered by the author in silent and adequately lit rooms with the help of a teacher who underwent ad hoc training. Oral tests were recorded and separately assessed by the author on the advice of a psychologist $^{3}$.

Analyses were conducted on Z-scores. Naming speed, partial syntactic comprehension scores, and clitic production are not provided with normative data, so $Z$-scores for these performances were calculated on the mean and standard deviation of the respective $\mathrm{CG}$.

\footnotetext{
${ }^{2}$ Data were collected from November 2016 to March 2017.

${ }^{3}$ Thanks to Letizia Moretti for her kind advice in the administration and assessment of reading tests.
} 


\section{REsults}

Table 1 illustrates the mean and standard deviation of $Z$-scores obtained by the groups on each test.

$\mathrm{DD}$

SLIG

$\mathrm{CG}$

\begin{tabular}{|c|c|c|c|c|c|}
\hline & $\begin{array}{c}\text { Age } \\
6 ; 7-9 ; 3\end{array}$ & $\begin{array}{c}\text { Age } \\
9 ; 5-11 ; 3\end{array}$ & $\begin{array}{c}\text { Age } \\
6 ; 7-9 ; 3\end{array}$ & $\begin{array}{c}\text { Age } \\
6 ; 7-9 ; 3\end{array}$ & $\begin{array}{l}\text { Age } \\
9 ; 5- \\
11 ; 3 \\
\end{array}$ \\
\hline & $\begin{array}{c}M \\
(S D)\end{array}$ & $\begin{array}{c}M \\
(S D)\end{array}$ & $\begin{array}{c}M \\
(S D)\end{array}$ & $\begin{array}{c}M \\
(S D)\end{array}$ & $\begin{array}{c}M \\
(S D)\end{array}$ \\
\hline $\begin{array}{c}\text { Decoding accu- } \\
\text { racy } \\
(Z)\end{array}$ & $\begin{array}{l}-1.15 \\
(0.70)\end{array}$ & $\begin{array}{l}-1.48 \\
(1.94)\end{array}$ & $\begin{array}{r}-5.13 \\
(4.45)\end{array}$ & $\begin{array}{l}-0.05 \\
(0.86)\end{array}$ & $\begin{array}{l}0.13 \\
(0.59)\end{array}$ \\
\hline $\begin{array}{l}\text { Decoding speed } \\
(Z)\end{array}$ & $\begin{array}{l}-1.18 \\
(0.90)\end{array}$ & $\begin{array}{r}-0.90 \\
(0.75)\end{array}$ & $\begin{array}{l}-1.18 \\
(1.43)\end{array}$ & $\begin{array}{c}0.47 \\
(0.71)\end{array}$ & $\begin{array}{r}-0.12 \\
(0.61)\end{array}$ \\
\hline $\begin{array}{l}\text { Reading com- } \\
\text { prehension }(Z)\end{array}$ & $\begin{array}{l}-0.69 \\
(2.10)\end{array}$ & $\begin{array}{c}0.13 \\
(0.77)\end{array}$ & $\begin{array}{l}-1.13 \\
(1.88)\end{array}$ & $\begin{array}{c}0.59 \\
(0.58)\end{array}$ & $\begin{array}{c}0.80 \\
(0.43)\end{array}$ \\
\hline $\begin{array}{c}\text { Naming accu- } \\
\text { racy }(Z)\end{array}$ & $\begin{array}{l}-0.26 \\
(0.53) \\
\end{array}$ & $\begin{array}{l}-0.83 \\
(0.75) \\
\end{array}$ & $\begin{array}{l}-1.30 \\
(0.95) \\
\end{array}$ & $\begin{array}{l}-0.03 \\
(0.95) \\
\end{array}$ & $\begin{array}{l}-0.51 \\
(0.64) \\
\end{array}$ \\
\hline $\begin{array}{c}\text { Naming speed } \\
(Z)\end{array}$ & $\begin{array}{l}-0.34 \\
(1.18)\end{array}$ & $\begin{array}{c}0.13 \\
(1.39)\end{array}$ & $\begin{array}{c}-0.4000 \\
(1.18)\end{array}$ & $\begin{array}{c}0.04 \\
(0.99)\end{array}$ & $\begin{array}{c}0.01 \\
(1.00)\end{array}$ \\
\hline $\begin{array}{l}\text { Syntactic com- } \\
\text { prehension } \\
\text { (global } Z \text {-score) }\end{array}$ & $\begin{array}{l}0.14 \\
(0.54)\end{array}$ & $\begin{array}{l}-0.33 \\
(1.00)\end{array}$ & $\begin{array}{l}-0.62 \\
(0.49)\end{array}$ & $\begin{array}{l}-0.12 \\
(0.96)\end{array}$ & $\begin{array}{l}-0.09 \\
(0.86)\end{array}$ \\
\hline $\begin{array}{l}\text { Syntactic com- } \\
\text { prehension (lex- } \\
\text { ical } Z \text {-score) }\end{array}$ & $\begin{array}{r}-0.72 \\
(1.53)\end{array}$ & $\begin{array}{l}-0.30 \\
(1.40)\end{array}$ & $\begin{array}{c}0.4 \\
(0.00)\end{array}$ & $\begin{array}{r}-0.02 \\
(1.03)\end{array}$ & $\begin{array}{c}0.00 \\
(1.04)\end{array}$ \\
\hline $\begin{array}{c}\text { Syntactic com- } \\
\text { prehension } \\
\text { (grammar } Z \text { - } \\
\text { score) } \\
\end{array}$ & $\begin{array}{l}-0.08 \\
(1.06)\end{array}$ & $\begin{array}{l}-0.40 \\
(1.00)\end{array}$ & $\begin{array}{l}-1.03 \\
(0.35)\end{array}$ & $\begin{array}{l}-0.01 \\
(0.99)\end{array}$ & $\begin{array}{r}-0.02 \\
(0.98)\end{array}$ \\
\hline $\begin{array}{l}\text { Clitic produc- } \\
\text { tion }(Z)\end{array}$ & $\begin{array}{l}-0.06 \\
(0.45)\end{array}$ & $\begin{array}{r}-0.63 \\
(1.78)\end{array}$ & $\begin{array}{l}-1.35 \\
(1.21)\end{array}$ & $\begin{array}{l}-0.01 \\
(0.98)\end{array}$ & $\begin{array}{c}0.00 \\
(0.99)\end{array}$ \\
\hline
\end{tabular}

Table 1: General results (Z-score)

Parametric/non-parametric (Kruskal-Wallis) Anovas revealed significant effects of group for decoding accuracy $(H(2)=7.702, p=0.021)$, decoding speed $(H(2)=12.518, p=0.002)$, naming accuracy $(F(2,26)=3.374, p=$ $0.050)$, and clitic production $(H(2)=6.059, p=0.048)$ The results of post hoc analyses before and after Bonferroni correction are in table 2. 
Age $(6 ; 7-9 ; 3)$

\begin{tabular}{|c|c|c|}
\hline & Contrast $(p)$ & Bonferroni $(p)$ \\
\hline Decoding accuracy & $\begin{array}{c}\text { DDG } 1<\text { CG1 }(0.033) \\
\text { SLIG < CG1 }(0.038) \\
\text { DDG1 }=\text { SLIG }(0.880)\end{array}$ & 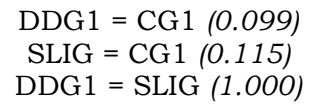 \\
\hline Decoding speed & $\begin{array}{c}\text { DDG } 1<\text { CG1 }(0.002) \\
\text { SLIG }<\text { CG1 }(0.021) \\
\text { DDG1 }=\text { SLIG }(0.687)\end{array}$ & $\begin{array}{c}\text { DDG } 1<\text { CG1 }(0.007) \\
\text { SLIG }=\text { CG1 }(0.064) \\
\text { DDG1 }=\text { SLIG }(1.000)\end{array}$ \\
\hline Naming accuracy & $\begin{array}{c}\text { DDG } 1=\text { CG1 }(0.602) \\
\text { SLIG }<\text { CG1 }(0.022) \\
\text { DDG1 }=\text { SLIG }(0.075)\end{array}$ & $\begin{array}{c}\text { DDG1 }=\text { CG1 }(1.000) \\
\text { SLIG }<\text { CG1 }(0.046) \\
\text { DDG1 }=\text { SLIG }(0.287)\end{array}$ \\
\hline Clitic production & $\begin{array}{c}\text { DDG } 1=\text { CG } 1(0.187) \\
\text { SLIG < CG1 }(0.022) \\
\text { SLIG = DDG1 }(0.379)\end{array}$ & $\begin{array}{c}\mathrm{DDG} 1=\mathrm{CG} 1(0.560) \\
\text { SLIG = CG } 1(0.067) \\
\text { SLIG }=\text { DDG } 1\end{array}$ \\
\hline
\end{tabular}

Table 2: Post hoc results in the younger group

As for syntactic comprehension, there was no significant difference between groups. In the SLIG, scores obtained on grammar-focused items were significantly lower than those obtained on lexicon-focused items $(U<0.001$, $p=0.029$ ).

In the elder sample, parametric (Student) and non-parametric (MannWhitney) independent sample tests confirmed that $Z$-scores of the DDG2 are significantly lower than those of the CG2 on decoding accuracy $(t(13.048)=$ - 2.746, $p=0.017)$, decoding speed $(t(21.093)=-2.799, p=0.011)$, and reading comprehension $(U=34.500, p=0.028)$.

\subsection{DECODING ERRORS}

Reading errors were analyzed in a cognitive psychology framework based on the "dual-route reading model" (Coltheart et al., 2001). Errors were classified according to the following taxonomy, which has been adapted from Friedmann and Coltheart (2018):

- LP (letter position errors): migration of letters within words, e.g. dispiacere -*despicare, pazientemente -*pazientamente;

- ATT (attentional errors): migration of letters across words, e.g. dal tettodal letto; se mi hai letto-se mai hai letto;

- LI (letter identity errors): omission or change of single consonant letters within words, e.g. dal-al; babbo-*papo;

- VIS (visual errors): errors of identification, omission, addition, withinword position, and letter-to-word binding of more letters leading to a visually similar word or pseudoword, e.g. pretendeva - prendeva; incontrarono - *intrarono;

- MULTI (multi-letter errors): errors in decoding complex and non-shallow letter clusters, e.g. cresceva - *crescheva; si ruppe - *si rumpe; 
- VOW (vowel errors): omission, addition, substitution, or transposition of vowel letters, e.g. dimissioni - *dimessioni; appena - *appina;

- SURF (surface errors): accent transposition in regular and irregular words, e.g. ripeté-ripete; fràdicia - *fradicia;

- MORPH (morphology errors): omission, addition, and change of letters, syllables or entire words leading to morphology errors, e.g. in compenso il compenso; dimenticando - dimenticato;

- SEM (semantic errors), e.g. ripeté - ribatté; a bocca aperta - a mano aperta.

Table 3 illustrates the proportion of error categories for each group

\begin{tabular}{cccccc} 
& \multicolumn{2}{c}{ DD } & SLI & \multicolumn{2}{c}{ CG } \\
\hline & $\begin{array}{c}\text { Age } \\
6 ; 7-9 ; 3\end{array}$ & $\begin{array}{c}\text { Age } \\
9 ; 5-11 ; 3\end{array}$ & $\begin{array}{c}\text { Age } \\
6 ; 7-9 ; 3\end{array}$ & $\begin{array}{c}\text { Age } \\
6 ; 7-9 ; 3\end{array}$ & $\begin{array}{c}\text { Age } \\
9 ; 5- \\
11 ; 3\end{array}$ \\
\hline LP & 2.9 & 9.6 & 6.1 & 2.4 & 0 \\
\hline ATT & 5.9 & 6.4 & 0 & 5.9 & 7.9 \\
\hline LI & 2.9 & 4 & 18.2 & 5.9 & 6.3 \\
\hline VIS & 8.8 & 6.4 & 1.5 & 4.7 & 14.3 \\
\hline MULTI & 11.8 & 20 & 37.9 & 11.8 & 17.5 \\
\hline VOW & 23.5 & 12.8 & 15.2 & 20 & 11.1 \\
\hline SURF & 2.9 & 6.4 & 7.6 & 4.7 & 7.9 \\
\hline MORPH & 41.2 & 32.8 & 13.6 & 43.5 & 33.3 \\
\hline SEM & 0 & 1.6 & 0 & 1.2 & 1.6 \\
\hline
\end{tabular}

Table 3: Proportions of reading errors (\%)

Among younger children, there was a significant association between group and error type (Fisher $=43,600, p<0.001 ; V=0.345, p<0.001$ ). Post hoc analyses (Bonferroni) showed that the SLIG $(Z=4.2)$ made significantly more MULTI errors than the CG1 $(Z=-2.9)$ and the DDG1 $(Z=-1.5)$; the $\operatorname{SLIG}(Z=-4.1)$ made also significantly less MORPH than the DDG1 $(Z=1.2)$ and the $\operatorname{CG} 1(Z=3.0)(p \leq 0.05)$.

Among elder children, there was no significant association between group and error type. The DDG2 $(Z=2.5)$ made significantly more LP than the CG2 $(Z=-2.5)(p \leq 0.05)$.

\subsection{RAPID NAMING RESPONSES}

In this section, the response analysis conducted in Casani (2019) is reported. Naming responses were classified as follows:

RIGHT: correctly named objects;

MISSING: missing responses;

SEMEs: semantic errors, e.g. zanzara [mosquito] instead of mosca [fly]; 
PHoEs: phonological errors, e.g. *lavantino instead of lavandino;

STRES: structural errors, e.g. cerchio [circle] instead of posacenere [ashtray];

OTHER: unconventional errors, e.g. coso [thingy] instead of mosca; dell'acqua [of the water] instead of rubinetto [tap].

Proportions of naming responses are in table 4.

\begin{tabular}{cccccc}
\multicolumn{2}{c}{ DDG } & SLI & \multicolumn{2}{c}{ CG } \\
\hline $\begin{array}{c}\text { Re- } \\
\text { sponses }\end{array}$ & $\begin{array}{c}\text { Age } \\
6 ; 7-9 ; 3\end{array}$ & $\begin{array}{c}\text { Age } \\
9 ; 5-11 ; 3\end{array}$ & $\begin{array}{c}\text { Age } \\
6 ; 7-9 ; 3\end{array}$ & $\begin{array}{c}\text { Age } \\
6 ; 7-9 ; 3\end{array}$ & $\begin{array}{c}\text { Age } \\
9 ; 5-11 ; 3\end{array}$ \\
\hline RIGHT & 69.0 & 74.2 & 51.3 & 73.3 & 67.9 \\
\hline MISSING & 7.0 & 9.6 & 13.8 & 12.0 & 7.5 \\
\hline SEMES & 18.0 & 13.3 & 22.5 & 12.8 & 20.8 \\
\hline PHOES & 3.0 & 1.3 & 7.5 & 1.3 & 1.3 \\
\hline STRUES & 1.0 & 1.3 & 0.0 & 0.5 & 0.4 \\
\hline OTHER & 2.0 & 0.4 & 5.0 & 0.3 & 2.1 \\
\hline
\end{tabular}

Table 4: Proportions of naming responses $(\%)$

In the younger group, there was a significant association between group and response type (Fisher $=33.075, p<0.001$ ). Post hoc analyses (Bonferroni) revealed that the SLIG gave significantly less right answers $(Z=-3.8)$ than both the DDG1 $(Z=-0,1)$ and the CG1 $(Z=2,9)$. The SLIG made significantly more PHOES $(Z=3.2)$ and OTHER errors $(Z=3.3)$ than the CG1 (PHOEs: $Z=-2,7$; OTHER: $Z=-3.1)(p \leq 0.05)$.

In the elder group, the association between group and response type was not significant.

\subsection{SYNTACTIC COMPREHENSION RESPONSES}

Table 5 reports proportions of accuracy for each item of the syntactic comprehension test where significant error proportions were found (Casani, 2019).

\begin{tabular}{|c|c|c|c|c|c|}
\hline & \multicolumn{2}{|c|}{ DD } & SLIG & \multicolumn{2}{|c|}{ CG } \\
\hline Item & $\begin{array}{c}\text { Age } \\
6 ; 7- \\
9 ; 3 \\
\end{array}$ & $\begin{array}{c}\text { Age } \\
9 ; 5- \\
11 ; 3 \\
\end{array}$ & $\begin{array}{c}\text { Age } \\
6 ; 7- \\
9 ; 3 \\
\end{array}$ & $\begin{array}{c}\text { Age } \\
6 ; 7- \\
9 ; 3 \\
\end{array}$ & $\begin{array}{c}\text { Age } \\
9 ; 5- \\
11 ; 3 \\
\end{array}$ \\
\hline $\begin{array}{l}\text { 11. "La matita è sulla scatola" } \\
\text { [The pencil is on the box] }\end{array}$ & 100,0 & 100,0 & 75,0 & 90,0 & 75,0 \\
\hline $\begin{array}{l}\text { 12. "Il ragazzo che sta inseguendo il } \\
\text { cavallo è grasso" } \\
\text { [The boy who is chasing the horse is } \\
\text { fat] }\end{array}$ & 100,0 & 91,7 & 75,0 & 70,0 & 83,3 \\
\hline $\begin{array}{l}\text { 13. "Il cavallo, ma non il ragazzo, sta in } \\
\text { piedi" }\end{array}$ & 60,0 & 58,3 & 50,0 & 45,0 & 66,7 \\
\hline
\end{tabular}


[The horse but not the boy is stand-

ing]

17. "Né il ragazzo né il cavallo stanno correndo"

[Neither the boy nor the horse are running]

18. "Il ragazzo inseguito dal cane è grande"

[The boy chased by the dog is big]

$\begin{array}{lllll}40,0 & 58,3 & 50,0 & 75,0 & 91,7 \\ 60,0 & 75,0 & 0,0 & 35,0 & 91,7\end{array}$

Table 5: Proportions of accuracy for syntactic comprehension items (\%)

In the younger group, the association between group and item was significant for the SLIG (Fisher $=23.470, p=0.014 ; V=0.657, p=0.020$ ) and the CG1 (Fisher $=86.454, p<0.001 ; V=0.558, p<0.001$ ). Post hoc tests (Bonferroni) revealed that the SLIG was significantly more likely to mistake item n. $18(Z=-4.0)$, and the CG1 item n. $12(Z=-2.2)$, n. $13(Z=-5.6)$, and n. $18(Z=-6.9)$. Moreover, the DDG1 revealed to be significantly more likely to mistake item n. $17(Z=-2.8)(p<0.05)$.

In the elder group, the association between group and item was significant for the DDG2 (Fisher $=29.885, p<0.001 ; V=0.445, p<0.001$ ) and the CG2 (Fisher $=20.600, p=0.017 ; V=0.382, p=0.017$ ). Post hoc tests (Bonferroni) revealed that the DDG2 was significantly more likely to mistake item n. 13 and $17(Z=-3.7)$, and the CG2 item n. $11(Z=-2.5)$ and $13(Z=$ - 3.7) $(p \leq 0.05)$.

\subsection{Clitic PROduction Responses}

Following Cardinaletti and Casani (2019), clitic production responses were classified as follows:

- TARGET: production of an appropriate DOcl;

- CE (Clitic Error): wrong clitic pronoun due to errors in gender, number and/or case, e.g. "Lo (MASC.DOcl) mangia" [It (DOcl) eats] instead of " $L a$ (FEM.DOcl) sta mangiando" [It (DOcl) is eating];

- $\mathrm{CO}$ (Clitic Omission): production of an ungrammatical phrase lacking the argument, e.g. "Sta dipingendo" ["Is painting] instead of "La (FEM.DOcl) sta dipingendo" [It (DO) is painting];

- DP (Determiner Phrase), production of a grammatical phrase containing a full DP in place of the DOcl, e.g. "Sta distruggendo il castello" [is destroying the castle] instead of "Lo (MASC.DOcl) sta distruggendo" [It (DOcl) is destroying];

- IC (Indirect Clitic), production of a grammatical phrase containing an indirect clitic in place of the DOcl, e.g. "Gli (IC) butta l'acqua addosso" [Him (IC) throws the water on] instead of "Lo (MASC.DOcl) sta bagnando" [Him (DOcl) is wetting]; 
- $\mathrm{CC}$ (Clitic Contraction): production of a grammatical phrase containing a present perfect with an elided clitic pronoun instead of the more appropriate present continuous with the full clitic, e.g. " $L$ '(MASC./FEM. DOcl) ha mangiato" [It (DOcl) has eaten] instead of "Lo (MASC.DOcl) sta mangiando" [It (DOcl) is eating];

- OTHER (out-of-context responses), e.g. "Per essere pulito" [To be clean] instead of "Lo (MASC.DOcl) sta lavando" [Him (DOcl) is washing].

Clitic production responses by different groups are in table 6 .

\begin{tabular}{cccccc}
\multicolumn{2}{c}{ DDG } & SLI & \multicolumn{2}{c}{ CG } \\
\hline \multirow{2}{*}{ Response } & Age & Age & Age & Age & Age \\
& $6 ; 7-9 ; 3$ & $9 ; 5-11 ; 3$ & $6 ; 7-9 ; 3$ & $6 ; 7-9 ; 3$ & $9 ; 5-$ \\
& 61,7 & 76,4 & 12,5 & 71,3 & 70,1 \\
\hline TARGET & 0.0 & 0.0 & 0.0 & 0.4 & 0.0 \\
\hline CE & 1,7 & 2,8 & 0.0 & 0,8 & 1.4 \\
\hline CO & 0.0 & 2,8 & 0.0 & 0,4 & 3.5 \\
\hline IC & 15,0 & 4,2 & 45.8 & 15 & 6,3 \\
\hline DP & 18,3 & 13,2 & 18,8 & 6,3 & 18,8 \\
\hline CC & 3,3 & 0,7 & 22,9 & 5,8 & 0,0 \\
\hline OTHER & & 0,7
\end{tabular}

Table 6: Proportions of clitic production responses (\%)

In the younger group, there was a significant association between group and response type (Fisher $=72.979, p<0.001 ; V=0.323, p<0.001$ ). Post hoc analyses (Bonferroni) revealed that the SLIG produced significantly less target answers $(Z=-7.5)$ and significantly more DPs $(Z=5.0)$ and OTHER phrases $(Z=4.2)$ than the DDG1 (TARGET: $Z=0$; DP: $Z=-0.9$; OTHER: $Z=-$ 1.4 ) and the CG1 (TARGET: $Z=5.6$; DP: $Z=-3.0$; OTHER: $Z=-2.0$ ). The SLIG $(Z=2.2)$ and the DDG1 $(Z=2.3)$ produced significantly more CC than the CG1 $(Z=-3.5)(p \leq 0.05)$.

In the elder group, there was no significant association between group and response type and no significant difference between groups.

\subsection{Correlations}

Tables 7 and 8 show significant correlations found in the younger and elder group respectively. Double asterisks indicate stronger relations.

Age 6;7-9:3

\begin{tabular}{cccc}
\hline Group & Variable 1 & Variable 2 & Spearman $\varrho(p)$ \\
\hline \multirow{2}{*}{ DDG1 } & $\begin{array}{c}\text { Syntactic compre- } \\
\text { hension }\end{array}$ & Reading comprehension & $0.949^{*}(0.014)$ \\
\hline SLIG & --- & --- & --- \\
\hline CG-1 & Naming speed & Naming accuracy & $0.575^{* *}(0.008)$ \\
\cline { 2 - 4 } & Decoding speed & Decoding accuracy & $0.652^{* *}(0.002)$ \\
\cline { 2 - 4 } & Decoding speed & Reading comprehension & $0.557^{*}(0.011)$
\end{tabular}


Clitic production

Clitic production

Decoding accuracy

Decoding speed

$0,462 *(0,040)$

Table 7: Correlations in the younger sample

$0,467 *(0,038)$

Age $9 ; 5-11 ; 3$

\begin{tabular}{cccc}
\hline Group & Variable 1 & Variable 2 & Spearman $\varrho(p)$ \\
\hline DDG-2 & ---- & --- & --- \\
\hline CG-2 & Naming accuracy & Decoding speed & $0.599^{*}(0.040)$ \\
\cline { 2 - 4 } & Decoding speed & Decoding accuracy & $0.677^{*}(0.016)$ \\
\hline
\end{tabular}

Table 8: Correlations in the elder sample

\section{Discussion}

We tested reading, rapid naming, syntactic comprehension and syntactic production in a group of Italian dyslexic children with and without SLI compared to a group of TD children. Replicating previous results (Casani, 2019; 2020), we found significant differences in reading, naming accuracy, and syntactic production of DOcl. Some differences emerged among children of different ages. Quantitative analyses showed that, while reading speed is a cross-age problematic aspect, accuracy and comprehension seem to be more problematic for the DDG2, who showed a significantly worse reading performance than the CG2 in terms of accuracy, speed, and comprehension. The reasons might be various. Accuracy is generally not considered as the more reliable index for DD in languages with a shallow orthography. In this regard, Zoccolotti et al. (2005: 39) find that accuracy in Italian is a more sensitive parameter in first grades than later. In the same work, they show an asymmetric situation as primary school grades increase, with an evident improvement only in secondary school. Casani (2019) supposes that standardized reading tests might affect children's reading performances for both decoding and speed. In first grades, texts employed are shorter, denotative, and present some images which may support expectation and comprehension, especially among children with a visual cognitive style. As the target age increases, greater length of texts may overload the working memory, which is generally recognized as a weak point of DD children (for a review, see Snowling, 2000; for recent studies on English and Italian children, respectively, see Gathercole et al., 2006; Menghini et al., 2011). Moreover, reading comprehension can be made harder by the presence of relatively inferential questions, which are employed for the last grades of primary school. More recent diagnostic tests (Cornoldi and Carretti, 2016) address this issue through the distinction between specific and central questions, the former being denotative and the latter more inferential, thus allowing to investigate the nature of possible comprehension problems. A third explanation might be a statistical effect due to the smallness of the younger experimental samples, which consist of 5 DD and 4 SLI children. Furthermore, one SLI child could not read, so that her accuracy score could not be com- 
puted. Single independent sample contrasts (table 2) show that reading accuracy of the experimental samples is statistically lower than that of the CG1 but this significance is not maintained after post hoc correction (Bonferroni) for multiple comparisons. This means that decoding accuracy differences between groups are at the limit and we could probably find significant post hoc differences if we extended the younger experimental samples (see Casani, 2020). The same reason can explain the quantitative results in clitic production (table 2), where the difference between the SLIG and the CG is also significant before but not after post hoc correction. Analyses of reading errors (table 3) and clitic production responses (table 6) show that significant differences between groups for both decoding accuracy and clitic production emerge, provided that a qualitative fine-grained analysis is conducted. In particular, the analysis of reading errors revealed that the SLIG has significant problems in decoding multi-letter compounds. This might be compatible with a phonological deficit (Friedmann and Coltheart, 2018), even considering that the same group makes $15.2 \%$ of VOW errors and $18.2 \%$ of LI errors. A reading test including pseudo-words may provide further insight into the nature of their disorder, whether sublexical (central) or visual (peripheral). At the same time, including pro-paroxytone and atypically accented words may help realize whether $7.6 \%$ of surface errors made by the SLIG might increase and be attributable to a deficit in the lexical reading route or not. With this purpose, Traficante et al. (2017) are adapting the Hebrew TILTAN battery (Friedmann and Gvion, 2003) to diagnose different kinds of DD even in a shallow orthography like the Italian one. The DDG1 and the CG1 showed a significant difficulty in decoding morphological compounds. As they do not make semantic errors in reading, their deficit does not seem ascribable to deep dyslexia. We wonder what the reason is for such a high proportion of MORPH errors in the DDG1 (41.2\%) and particularly, in the CG1 (43.5\%). An analysis of single performances did not show any significant association between MORPH errors and any subject in any of the groups. We could then hypothesize a general weakness in their morphological lexicon as well as an impairment (for the DDG1) or delay in the acquisition of the orthographic reading step (Frith, 1985), possibly due to their young age (for the CG1). In this case, the question would be why the agematched SLIG does not present comparable problems. The analysis of single performances in the SLIG showed that MORPH errors are significantly associated to one subject (Fisher $=23.414, p=0.004 ; Z=5.2, p \leq 0.05 ; V=$ $0.526, p=0.001$ ) aged $8 ; 11$, who made only this error type and showed the lowest error proportion in the SLIG (6\% of total errors, against 38\% and 56\% of the other two SLI children who could read). Her reading errors mainly consisted of part-of-speech substitutions. As for other tests, she showed a performance at risk in the syntactic comprehension of grammar-focused items $(Z=-1.2)$, and a weak performance in syntactic production $(Z=-1.5)$, where she replaced $75 \%$ of target clitics with full DPs. In the naming test, 
she showed an average accuracy and very good speed. We could then suppose the presence of an underlying morphosyntactic deficit which may influence decoding by preventing lexical retrieval of visually similar parts of speech (di-si; no-non). A battery that contains a focus on reading visually similar words with contrastive morphological status might shed light on this question. These results are not completely in line with either the "Simple View of Reading" (Hoover and Gough, 1990) (see section 1), as younger children do not show reading comprehension problems, or results by Bishop and Snowling (2004), as SLI-children cannot be distinguished from DD-only children because of a reading comprehension difficulty in addition to decoding problems.

Concerning rapid naming, there is surprisingly no difference in speed, meaning that DD and SLI children are not necessarily slower than TD children in naming tasks. Casani (2020) explains this outcome through the "double deficit hypothesis" (Wolf and Bowers, 1999), according to which the naming speed deficit and the phonological deficit can be two separable predictors of the reading disorder. The response analysis showed that SLI-children are significantly less accurate than both the CG1 and the DDG1, and make significant proportions of PhoEs and atypical errors. A significant presence of PhoEs may be evidence of an expressive SLI rather than a phonological deficit (Lahey and Edwards, 1999). If the present results should be confirmed on wider samples, we could wonder whether a double deficit (naming accuracy + decoding) might be a marker of SLI among children with DD.

As for syntactic comprehension, analyses of general scores showed no significant difference between groups. The SLIG, however, revealed significant difficulties in processing grammar-focused items, whereas they scored $100 \%$ on lexicon-focused items. Bishop (2009) states that problems with interpreting lexical items suggest the presence of comprehension difficulties that are other than morphosyntactic, namely problems in remembering words or integrating information from different parts of the phrase. Good outcomes on lexicon-focused items could then corroborate those obtained on grammar-focused items (Casani, 2019). The older CG gave a significant proportion of wrong responses for lexical item n. 11 (table 5), i.e. a declarative clause with a preposition (sulla [on the (FEM.ARTICULATED_PREP.)]) indicating a spatial relation ( $75 \%$ correctness). The difficulty with this item can lie in the interpretation of the preposition. All children who mistook this item chose the same wrong image (n. 2, in the authors' intention: "La matita è nella scatola" [The pencil is in the box]), showing a pencil that should be in the box but is actually half on the box (fig.1). Casani (2019) suggests that this item presents a certain ambiguity, which might affect the error proportion. In this case, it would be worth wondering why the CG2 appears to be less tolerant of ambiguity than other groups. 


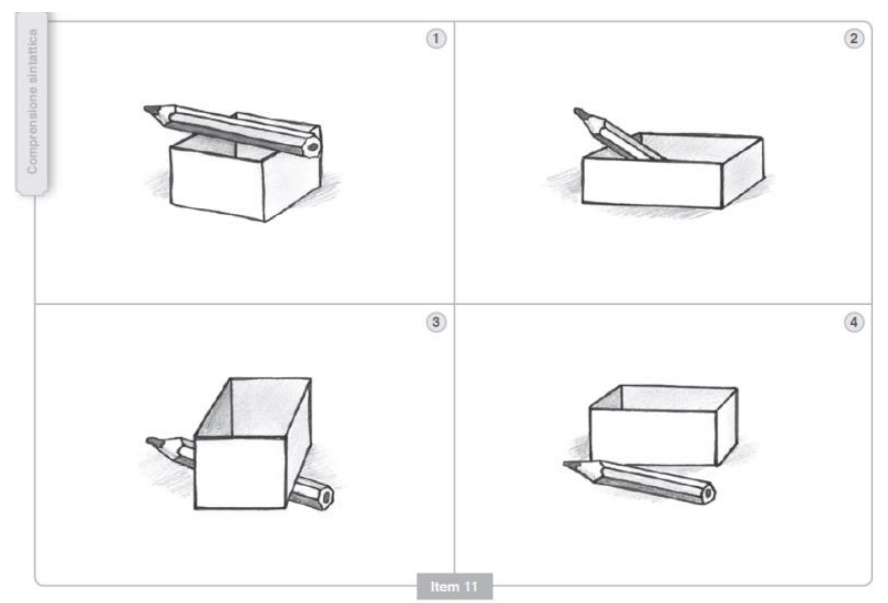

Figure 1: Item n. 11 of the syntactic-comprehension test (Bisiacchi et al., 2005)

The response analysis revealed some structures to be more problematic than others for some groups. A correlative clause with a double negated subject (item n. 17) was significantly problematic for both the younger and the older DDGs. The latter, as well as both the CGs, had also difficulties with a parenthetical adversative negative clause (item n. 13). Negative clauses can be particularly demanding for DD children when they are presented out of an explicit context, as in the case of a picture-sentence matching task where the picture does not provide the child with a representation of the event. This is in line with the 'two-step simulation hypothesis' (Kaup et al., 2007), which assumes that negation expresses a deviation from a prior expectancy. An embedded subject relative clause (item n. 12) was particularly problematic for the younger $\mathrm{CG}$, whereas a reduced passive relative clause (item n. 18) created significant problems to the SLIG $(0 \%)$ and the younger CG (35\%). SLI children usually have problems in processing passive sentences (Bishop et al., 2000) and object relative clauses (Adani et al., 2014) due to a deficit in syntactic movement (Friedmann and Novogrodsky, 2007). Italian TD children, anyway, can reach adult-like comprehension of passive clauses around age 5/6 (Volpato et al., 2013; 2016), and from age $6 ; 5$ they show better comprehension of passive than active object relatives so that they can use those to avoid production of active relatives (Contemori and Belletti, 2013). Casani (2019) supposes that

problems by the present younger CG may then be due to a delay in the acquisition of this complex structure, which, against expectations, seems instead to be quite well interpreted by the DDG [60\%]. [...] Considering that everyone but the SLIG had problems with some negative clause, difficulties with negative clauses seem to be cross-age and might be due more to a delay in grammar acquisition than to a particular disorder. Marked difficulties in interpreting object relative clauses may instead be related to a language deficit, as only the SLIG scored $0 \%$ on this structure. Younger TD children show some problems with this structure (35\% correctness), which are overcome as their age increases. 
Correlative negation seems to be particularly problematic for dyslexic children, as both DD groups made significant error proportions on this item. Although further experiments on wider samples are necessary to shed light on these issues, these reflections suggest that some syntactic comprehension tests that are commonly used in clinical practice might hide some difficulties that would rather emerge at a fine-grained analysis. Test developers could then consider the possibility to focus syntactic comprehension tests on structures that are reported as particularly demanding by the literature.

The response analysis confirms clitic omission as a good clinical marker of SLI, as the SLIG produced significantly fewer target clitics than both the age-matched groups (table 6). Replicating previous results (Arosio et al., 2010, 2014), SLI children replaced clitic pronouns with full DPs, which were significantly more numerous in the SLIG than in both the age-matched groups. Furthermore, both the SLIG and the DDG1 produced more elided clitics than the respective CG. These are interpreted as compensation strategies allowing the children to avoid complex (morpho)syntactic operations involved in clitic production by producing sentences that are grammatically correct but not pragmatically appropriate to the elicitation context (Cardinaletti and Casani, 2019). In particular, the production of full DPs is a syntactic avoiding strategy that allows to place the object in a canonical position and to interpret it locally, differently from the DOcl, which should be placed in a preverbal position and interpreted remotely. Clitic elision could be a morphology avoiding strategy which allows producing a correct DOcl by neutralizing gender and number phi features, thus avoiding the agreement with the remote antecedent. The result is a grammatically correct phrase that is not pragmatically appropriate for tense and aspect (ibidem).

The SLIG gave a significant proportion of atypical responses, but the analysis of single performances revealed these errors to be significantly associated with a single subject, who produced those in $92 \%$ of the cases. This might suggest the presence of a pragmatic deficit in that particular subject and highlights the importance of a qualitative approach to single performances, especially in case of such small samples. Cardinaletti and Casani (2019) found that a slightly higher cut-off age $(9 ; 6)$ is sufficient to determine a significant difference in the proportions of DOcls and DPs produced by the DDG 1 and the SLIG (Target: CG $>$ DDG $>$ SLIG; DPs: $C G<D D G<$ SLIG). Furthermore, after age 10, problems with DOcls by DD children are completely overcome, as proportions of target clitics and full DPs produced by the DDG and the CG do not significantly differ. These outcomes suggest that problems by DD children might be more ascribable to a delay in the acquisition of their grammar rather than to an undiagnosed SLI (as suggested by Guasti, 2013), as their strategies are quantitatively and qualitatively different from those of SLI-children. Furthermore, the main compensation strategy, namely DP production, is distributed along the DDG1 without any significant association to particular subjects. It seems unlikely that every subject of that group presents an undiagnosed SLI (Cardinaletti and Casani, 2019). 
The number of correlations between reading and other skills confirms to be proportional to the severity of the impairment, as no correlation is present in the SLIG, only one relation is present in the younger DDG, and several relations are present in the CGs (tables 7 and 8). In particular, in the DDG1, syntactic comprehension is significantly related to reading comprehension but this relation disappears in the DDG2. In the CG1, reading comprehension is significantly related to decoding speed but this relation disappears in the CG2. This might be evidence of an evolution in comprehension strategies of elder children: in the first phases of reading acquisition, they would be more tied to the text, whereas in the subsequent phases they might exploit other elements, such as contextual aspects, which would enable them to get "the gist from a passage" (Hulme and Snowling, 2009: 127). In the CG1, decoding accuracy and speed are related to clitic production, whereas in the CG2, naming accuracy is related to decoding speed. In both CGs, decoding speed is related to decoding accuracy. These patterns, which confirm in principle previous results obtained by the analyses of raw scores and $Z$ scores of the global sample, suggest that all

these [reading]-related skills that are present only among TD-children might provide a series of clues in support of reading [...] which would be absent among impaired subjects. Good lexicon-retrieval skills coupled with good (morpho)syntactic skills may support the reader's expectancy grammar (Oller, 1979), thus making reading more fluent and effective. This hypothesis is consistent with extensive research by Maryanne Wolf, who also developed a method aiming at improving children's written decoding and comprehension through explicit teaching of different phonological, semantic, and (morpho)syntactic representational systems involved in reading (Wolf et al., 2009) (Casani, 2020).

\section{Conclusion}

In this study, a group of dyslexic children with and without SLI was tested in some language skills that are demanding for both DD and SLI to describe possible patterns that might be distinctive of different disorder profiles.

Experimental groups showed comparable reading performances, with some age-related differences. Error analyses based on text reading allowed to detect different error patterns and suggest that an ad hoc reading battery could be used to distinguish different kinds of DD.

Widening the sample could allow exploring more deeply decoding accuracy of younger impaired children and whether a particular kind of "double deficit" (naming accuracy + decoding) might be a marker of SLI among DDchildren.

Some syntactic comprehension tests that are commonly used in clinical practice might hide possible difficulties that would rather emerge at a qualitative fine-grained analysis. An implementation of such tests through a focus on sensitive structures is suggested. 
The omission of DOcls confirms to be a good clinical marker of SLI even in small samples, provided that a fine-grained response analysis is conducted. Typical strategic patterns are found among experimental samples, with significant qualitative and quantitative differences. This might be evidence of the different nature of clitic production problems of DD children compared to SLI children.

The quantity and nature of correlations between reading and other skills confirm to be proportional to the severity of the impairment. Rapid naming, which is recognized as a longitudinal predictor of decoding, is synchronically related to decoding only among elder TD readers. We wonder whether it would be possible to indirectly potentiate reading by strengthening its related abilities.

\section{REFERENCES}

ADANI, F. et al. (2014): "Number dissimilarities facilitate the comprehension of relative clauses in children with (Grammatical) Specific Language Impairment", Journal of Child Language, 41, pp. 811841.

AROSIO, F. et al. (2014): "Failure to produce direct object clitic pronouns as a clinical marker of SLI in school-aged Italian speaking children", Clinical Linguistics and Phonetics, 28 (9), pp. 639-663.

AROSIO, F. et al. (2010): "SLI Children's weakness in Morphosyntax and Pragmatics", Otsu, Y. (ed.), The Proceedings of the 11th Tokyo Conference on Psycholinguistics, Tokyo: Hituzi Publishing Company, pp. 5775.

BEFI-LOPES, D. M. et al. (2010): "Semantic representation and naming in children with specific language impairment", Pro Fono, 22 (2), pp. 113-118.

BISHOP, D. V. M. \& ADAMS, C. (1990): “A prospective study of the relationship between specific language impairment, phonological disorders and reading retardation", Journal of
Child Psychology and Psychiatry, 31, pp. 1027-1050. BISHOP, D. V. M. \& SNOWLING, M. J. (2004):

"Developmental dyslexia and specific language impairment: Same or different?", Psychological Bulletin, 130, pp. 858-886.

BISHOP, D. V. M. (2009): TROG-2. Test for Reception of Grammar Version 2, Firenze: Giunti.

BISHOP, D. V. M. et al. (2000): "Grammatical SLI: A distinct subtype of developmental language impairment?", Applied Psycholinguistics, 21 (2), pp. 159-181.

BISHOP, D. V. M. et al. (2009): "Children who read words accurately despite language impairment: Who are they and how do they do it?", Child Development, 80, pp. 593-605.

BISHOP, D. V. M. (1997): Uncommon understanding: development and disorders of language comprehension in children, Hove: Psychology Press.

BISHOP, D V. M. (2006): "Beyond words: Phonological short-term memory and syntactic impairment in specific language impairment", Applied Psycholinguistics, 27, pp. 569573. 
BISIACCHI, P. S. et al. (2005): BVN 511. Batteria di valutazione neuropsicologica per l'età evolutiva, Trento: Erickson.

BORTOLINI, U. et al. (2006): "Clinical markers for specific language impairment in Italian: The contribution of clitics and nonword repetition", International Journal of Language and Communication Disorders, 41, pp. 695-712.

BYRNE, B. (1981): "Deficient syntactic control in poor reader: Is a week phonetic memory code responsible", Applied Psycholinguistics 2, pp. 201212.

CARDINALETTI, A. \& CASANI, E. (2019): "Pragmatica nell'uso dei pronomi clitici diretti di terza persona singolare in bambini dislessici con e senza disturbo specifico del linguaggio", Nuzzo, E. \& Vedder I. (eds.): Lingua in contesto. La prospettiva pragmatica, Bologna/Milano: AItLA - Associazione Italiana di Linguistica

Applicata/Officinaventuno, pp. 9-27.

CARDINALETTI, A. \& VOLPATO, F. (2015): "On the comprehension and production of passive sentences and relative clauses by Italian university students with dyslexia", Di Domenico, E.; Hamann, C. \& Matteini S. (eds.): Structures, Strategies and Beyond, Amsterdam: John Benjamins Linguistik Aktuell Series, pp. 279-302.

CASANI, E. (2019): “Correlations between oral and written key skills among Italian dyslexic children with and without SLI", Carbonara, V. et al. (eds.): Il parlato - Lo scritto. Aspetti teorici e didattici. Pisa: Pacini Editore, pp. 119-136.

CASANI, E. (2020): "Rapid naming, reading, comprehension, and syntactic production by Italian dyslexic children with and without specific language impairment", Levey, D. (ed.): Strategies and analyses of language and communication in multilingual and international contexts, Newcastle: Cambridge Scholars Publishing, pp. 111122.

CASTLES, A. et al. (2010): "Developmental dissociations between lexical reading and comprehension: evidence from two cases of hyperlexia", Cortex, 46 (10), pp. 1238-1247.

CATTS H. W. et al. (2005): "Are specific language impairment and dyslexia distinct disorders?", Journal of Speech, Language, and Hearing Research, 48, pp. 1378-1396.

CHOMSKY, N. (1993 [1981]): Lectures on Government and Binding: The Pisa Lectures, Berlin: De Gruyter Mouton.

CLARKE, P. et al. (2010): "Ameliorating children's reading-comprehension

difficulties: A randomized controlled trial", Psychological Science, 21, pp. 1106-1116.

CLAHSEN, H. et al. (1997): "Formal features in impaired grammars: A comparison of English and German SLI children", Journal of Neurolinguistics, 10, pp. 151171.

COLTHEART M. et al. (2001): "DRC: A dual route cascaded model of visual word recognition and reading aloud", Psychological Review, 108, pp. 204-256.

CONTEMORI, C. \& BELLETTI, A. (2013): "Relatives and Passive Object Relatives in Italian speaking children and adults: Intervention in production and comprehension", Psycholinguistics, pp. 1-33. 
CORNOLDI, C. \& CARRETTI, B. (2016): Prove MT-3 Clinica. La valutazione delle abilità di Lettura e Comprensione per la scuola primaria e secondaria di I grado, Firenze: Giunti Psychometrics.

CORNOLDI, C. \& COLPO, G. (2011): Prove di Lettura MT-2 per la Scuola Primaria, Firenze: Giunti.

DECKER, S. L. et al. (2013): “Cognitive predictors of rapid picture naming", Learning and Individual Differences, 25, pp. 141-149.

DENCKLA, M. B. \& RUDEL, R. G. (1976): "Naming of objectdrawings by dyslexic and other learning disabled children", Brain and Language, 3, pp. 115.

DOCKRELL, J. E. \& MESSER, D. (2007): "Language profiles and naming in children with word finding difficulties", Folia Phoniatr Logop, 59, pp. 318323.

FAWCETT, A. J. \& NICOLSON, R. I. (1994): "Naming speed in children with dyslexia", Journal of Learning Disabilities, 27, pp. 641-646.

FIORIN, G. (2010): Meaning and Dyslexia: A Study on Pronouns, Aspect, and Quantification (Ph.D. Dissertation), Utrecht: Utrecht Institute of Linguistics.

FRIEDMANN, N. \& COLTHEART, M. (2018): "Types of developmental dyslexia", Bar-On A. \& Ravid D. (eds.): Handbook of communication disorders: Theoretical, empirical, and applied linguistic perspectives, Berlin, Boston: De Gruyter Mouton, pp. 721-751.

FRIEDMANN, N. \& GVION, A. (2003b): TILTAN: Battery for the diagnosis of dyslexias, Tel Aviv University (in Hebrew).

FRIEDMANN, N. \& HADDAD-HANNA,
M. (2014): “Types of developmental dyslexia in Arabic", Saiegh-Haddad, E. \& Joshi, M. (eds.): Arabic Literacy: Theoretical Insights and Practical Challenges. Language and Literacy Series, The Netherlands: Springer, pp. 119152.

FRIEDMANN, N. \& NOVOGRODSKY, R. (2007): "Is the movement deficit in syntactic SLI related to traces or to thematic role transfer?", Brain and Language, 101, pp. 50-63.

FRIEDMANN, N. \& NOVOGRODSKY, R. (2008): "Subtypes of SLI", Gavarro, A. \& Freitas, J. M. (eds.): Language acquisition and development, Newcastle: Cambridge Scholar Press, pp. 205-217.

FRIEDMANN, N. \& NOVOGRODSKY, R. (2011): "Which questions are most difficult to understand?: The comprehension of Wh questions in three subtypes of SLI", Lingua 121 (3), pp. 367382.

FRITH, U. (1985): "Beneath the surface of surface dyslexia", Marshall J. C.; Coltheart M. \& Patterson K. (eds.): Surface dyslexia and surface dysgraphia, London: Routledge \& Kegan Paul, pp. 301-330.

FRITH, U. \& SNOWLING, M. (1983): "Reading for meaning and reading for sound in autistic and dyslexic children", British Journal of Developmental Psychology, 1 (4), pp. 329-342.

GATHERCOLE, S. E. et al. (2006): "Working memory in children with reading disabilities", Journal of Experimental Child Psychology, 93 (3), pp. 265281.

GRICE, P. (1975): "Logic and conversation", Cole P. \& Morgan, J. L. (eds.): Speech Acts, New York: Academic 
Press, pp. 41-58.

GUASTI, M. T. (2013): "Oral skills deficit in children with Developmental Dyslexia”, Stavrakaki, S.; Lalioti, M. \& Konstantinopoulou P. (eds.): Advances in Language Acquisition, Newcastle: Cambridge Scholars Press, pp. 416-424.

HOOVER, W. \& GOUGH, P. B. (1990): "The simple view of reading", Reading and Writing, 2, pp. 127-160.

HULME C. \& SNOWLING, M. J. (2009): Developmental Disorders of Language Learning and Cognition, Hoboken: Wiley.

HUMPHREYS, G .W. et al. (1990): "Orthographic processing in visual word identification", Cognitive Psychology, 22, pp. 517-560.

KATSOS, N. et al. (2011): "Are children with Specific Language Impairment competent with the pragmatics and logic of quantification?”, Cognition, 119 (1), pp. 43-57.

KAUP, B. et al. (2007): "The experiential view of language comprehension: How is negated text information represented?", Schmalhofer F. \& Perfetti C. A. (eds.): Higher level language processes in the brain: Inference and comprehension processes, Mahwah: Erlbaum, pp. 255288.

LAHEY M. \& EDWARDS J. (1999): "Naming errors of children with specific language impairment", Journal of Speech, Language, and Hearing Research, 42 (1), pp. 195-205.

LEONARD, L. B. (1995): "Functional categories in the grammars of children with specific language impairment", Journal of Speech, Language, and Hearing Research, 38, pp. 1270-1283.
LEONARD, L. B. (1998 [2014]): Children with specific language impairment, Cambridge: MIT Press.

MANIKA, S. (2014): Direct object clitics in Greek-speaking children with SLI (Master thesis), Utrecht: Utrecht University.

MANIS, F. R. et al. (1997): "Are speech perception deficits associated with developmental dyslexia?", Journal of Experimental Child Psychology, 66, pp. 211-235.

MARTIN, J. et al. (2010): "Reading in French-speaking adults with dyslexia", Annals of Dyslexia, 60 (2), 238-264.

MCGREGOR, K. K. et al. (2002): "Semantic representation and naming in children with specific language impairment", Journal of Speech, Language and Hearing Research, 45, pp. 998-1015.

MENGHINI, D. et al. (2011): "Working Memory Impairment in Children With Developmental Dyslexia: Is it Just a Phonological Deficity?", Developmental Neuropsychology, 36 (2), pp. 199-213.

MENYUK, M. \& LOONEY, P. L. (1972): "A problem of language disorder: Length versus structure", Journal of Speech and Hearing Research, 15, pp. 264-279.

MILES, T. R. (1993). Dyslexia: the pattern of difficulties, London: Whurr.

NATION, K. (2005): “Children's Reading Comprehension Difficulties", Snowling M. J. \& Hulme C. (eds.): The Science of Reading: A Handbook, Oxford: Blackwell Publishing Ltd., pp. 248-265.

NITHART C. et al. (2009): "Reading Disabilities in SLI and Dyslexia 
Result From Distinct Phonological Impairments", Developmental Neuropsychology, 34 (3), pp. 296-311.

OLLER J. W. JR. (1979): Language tests at school: A pragmatic approach, London: Longman.

PARSONS, T. (1990): Events in the Semantics of English: A Study in Subatomic Cambridge: MIT Press.

PATEL, T. K. et al. (2004): "Learning to read in Dutch and English: A crosslinguistic comparison", Journal of Educational Psychology, 96 (4), pp. 785797.

PERFETTI, C. A. (1985): Reading Ability, New York: Oxford University Press.

PETERSON, R. L. \& PENNINGTON, B. F. (2012): "Developmental Dyslexia", The Lancet, 379 (9830), pp. 1997-2007.

SEYMOUR, P. H. K. \& EVANS, H. M. (1992): "Beginning reading without semantics: A cognitive study of hyperlexia", Cognitive Neuropsychology, 9, pp. 89122.

SNOWLING, M. J. (2000): Dyslexia: A cognitive-developmental perspective, Oxford: Blackwell.

SPENCER, M. et al. (2014): "Specific Reading Comprehension Disability: Major Problem, Myth, or Misnomer?", Learning disabilities research \& practice, 29 (1), pp. 3-9.

STUART, M. \& HOWARD, D. (1995): "KJ: A developmental deep dyslexia", Cognitive Neuropsychology, 12, pp. 793824.

SWAN, D. \& GOSWAMI, U. (1997): "Picture naming deficits in developmental dyslexia: the phonological representations hypothesis", Brain and Language, 56, pp. 334-353.

TALLI, I. et al. (2015): "Is there an overlap between Specific
Language Impairment and Developmental Dyslexia? New insights from French", Language Acquisition and Language Disorders, 58, pp. 57-88.

TALLI, I. et al. (2016): "Specific language impairment and developmental dyslexia: What are the boundaries? Data from Greek children", Research in Developmental Disabilities, 4950, pp. 339-353.

TRAFICANTE, D. et al. (2017): "Multiple patterns of dyslexia in a shallow orthography: Principles for a diagnostic screening of developmental dyslexias", Abstract Academy of Aphasia 55th Annual Meeting (Baltimore, Maryland USA, 0507 November 2017), Frontiers in Human Neuroscience, 2017 (n/a), http:/ / hdl.handle.net/10807/ 115482 .

VAESSEN, A. et al. (2009): “Naming problems do not reflect a second, independent core deficit in dyslexia: double deficits explored", Journal of Experimental Child Psychology, 103, pp. 202-221.

VAN DER LELY, H. K. J. \& STOLLWERCK, L. (1997): "Binding theory and grammatical specific language impairment in children", Cognition, 62, pp. 245-290.

VAN DER LELY, H. K. J. et al. (2011): "Who did Buzz see someone? Grammaticality judgement of wh-questions in typically developing children and children with GrammaticalSLI", Lingua, 121 (3), pp. 408422.

VAN DER LELY, H. K. J. (2005): "Domain-specific cognitive systems: Insight from Grammatical-SLI", Trends in Cognitive Sciences, 9, pp. 53- 
59.

VENDER, M. \& DEL FITTO, D. (2010): "Towards a pragmatics of negation: the interpretation of negative sentences in developmental dyslexia", (GG@G) Generative Grammar At Geneva, 6, pp. 1-28.

WISEHEART, R. et al. (2009): "Sentence comprehension in young adults with developmental dyslexia", Annals of Dyslexia, 59 (2), pp. 151-167.

WOLF, M. \& OBREGON, M. (1992): "Early naming deficits, developmental dyslexia, and a specific deficit hypothesis", Brain and Language, 42, pp. 219-247.

WOLF, M. (2001): Dyslexia, fluency, and the brain, York: York Press Inc.

WOLF, M. \& BOWERS, P. G. (1999): "The double-deficit hypothesis for the developmental dyslexias", Journal of Educational Psychology, 91, pp. 415-438.

WOLF, M. et al. (1986): "Automaticity, retrieval processes, and reading: A longitudinal study in average and impaired readers", Child Development, 57, pp. 988-
1000.

WOLF, M. et al. (2009), "The RAVE-O Intervention: Connecting Neuroscience to the Classroom", Mind, Brain, and Education, 3 (2), pp. 65-129.

WOLFF, P. H. et al. (1990): "Rate and timing precision of motor coordination in developmental dyslexia", Developmental Psychology, 26, pp. 349-359.

ZACHOU, A. et al. (2013): "Production and comprehension of direct object clitics and definite articles by Italian children with developmental dyslexia", Stavrakaki, S.; Lalioti, M. \& Konstantinopoulou P. (eds.): Advances in Language Acquisition, Cambridge Scholars Press, Newcastle, pp. 464-471.

ZIEGLER, J. C. et al. (2010): "Orthographic depth and its impact on universal predictors of reading a cross-language investigation", Psychological Science, 21, pp. 551-559.

ZOCCOLOTTI, P. et al. (2005): I disturbi evolutivi di lettura $e$ scrittura. Manuale per la valutazione, Roma: Carocci. 